\title{
Comparative analysis of heavy metal contamination in some common tubers and vegetables of Kerala
}

\author{
Silvy Mathew* and P.T. Teenamol \\ Department of Botany, \\ Vimala College, Thrissur-680 009, Kerala, India. \\ Received: 02-10-2018 Accepted: 08-06-2019
}

DOI: 10.18805/IJARe.A-5142

\begin{abstract}
Leafy vegetables and tubers contaminated by heavy metals will cause potential health risk to human beings. An analysis was carried out to study the heavy metal contamination in tubers and leafy vegetables at Kottayam district, Kerala. The results indicated that higher levels of lead were recorded in all of the samples analyzed when compared to the WHO permissible limits $(0.1 \mathrm{mg} / \mathrm{kg})$ for tubers and leafy vegetables, except in Colocasia esculenta (L.) Schott., collected from Erattupetta market. Cadmium content was higher in both the tubers and leafy vegetables collected from Changanacherry market. Therefore, regular assessment of the accumulation of heavy metals in leafy vegetables and tubers is the need of the era.
\end{abstract}

Key words: Accumulation, Cadmium vegetables, Flame atomic absorption spectrophotometer, Health risk, Heavy metals, Lead, Tubers.

\section{INTRODUCTION}

Heavy metals are very toxic to human beings and plants and their mobile nature can move from bottom to top in plants and animals. Also the consumption of food items with heavy metal contamination is highly toxic to human beings. Some metals have importance in plant breeding or crop improvement. For example, Vijayata et al. (2017) studied that the genomic regions which were detected to be associated with high iron and zinc could be candidate for further fine mapping, gene identification and MAS in breeding. Also, Radmila Trajkovic et al. (2012) studied the influence of lead acetate and actinomycetes on germination and growth of vetch plant. Venkatesh et al. (2018) studied the response of zinc application on growth, zinc content and grain yield of rice genotypes and correlation between zinc content and yield attributes of rice genotypes. In their study the high and low seed zinc content genotypes showed negative correlation with yield and yield attributes. However, shoot zinc content was positively correlated with yield.

Several anthropogenic activities become the source of accumulation of heavy metals in air, soil and water. Industrialization, urbanization, soil contamination through mining, agronomic practices such as artificial fertilizers and metal based pesticides etc. will cause the increase in the heavy metal circulation through the soil (Uwah et al., 2011, Usman and Ayodele, 2002, Ndiokwere and Ezeh, 1990). For most of the toxic metals, mankind has become the key agent in the global atmospheric cycle of trace metals and metalloids.
Soil and vegetable samples are contaminated by toxic heavy metals and Fe concentration in soil variable in tomato and chilli and are crossed permissible limits (Smriti et al., 2017). Ashiq et al. (2013) found that the concentration of cadmium, lead and nickel were higher in the upper surface of tube well and surface irrigated soils at all the four depths $(0-15,15-30,30-45$ and $45-60 \mathrm{~cm})$, respectively and decrease in the lower surface. In relation with aquatic system, researchers found that based on the critical pollution index value (1491.5), river Yamuna is highly polluted due to anthropogenic activities (Richa et al., 2017). The studies on Telfairia occidentalis Hook. F. is believed to contain heavy metals and cause potential health risk to the consumers (Oguntibeju et al., 2013).

The consumption of leafy vegetables and tubers as food offer rapid and least means of providing adequate vitamins supplies minerals and fiber. Tubers are the most efficient carbohydrate producers. Heavy metal contamination of vegetables cannot be underestimated, as these foodstuffs are important components of human diet. Vegetables are rich sources of macro and micronutrients, vitamins, minerals, and fibers, and also have beneficial antioxidative effects (Agrawal et al., 2007). Tubers constitute the daily part of every human diet. Also, vegetables are very important source of our daily diet rich in carbohydrates, proteins and vitamins but unfortunately contain the accumulation and translocation of heavy metals (Sobukola, 2010). Asaolu et al., (2012) studied the proximate analysis and mineral composition of some Nigerian leafy vegetables and found that leafy

*Corresponding author's e-mail: silvymathew110@gmail.com 
vegetables contain high levels of crude protein with low fat content and crude fibres.

Akan et al., (2013) analyzed the heavy metal accumulation in freshly harvested vegetables from four locations of Nigeria. They realized that the leaves of vegetables contain high concentrations of heavy metals and anions than its roots and stems. Simul et al., (2017), estimated the concentration of globally alarming the heavy metals ( $\mathrm{Zn}$, $\mathrm{Al}, \mathrm{Cd}, \mathrm{Pb}, \mathrm{Cu}, \mathrm{Ni}, \mathrm{Fe}, \mathrm{Mn}, \mathrm{Cr}, \mathrm{Co}$ ) in Meghna River, Bangladesh. A very strong positive correlation was recorded between $\mathrm{Fe}$ vs $\mathrm{Al}$ (0.992), $\mathrm{Mn}$ vs $\mathrm{Cu}$ (0.948), Fe vs $\mathrm{Mn}$ (0.939), Zn vs Al (0.929), Fe vs Zn (0.920) in water. Murat et al., (2014) investigated the heavy metal accumulation in the leaves, stem and root of the invasive submerged Macrophyte Myriophyllum spicatum. According to the factor data of bioconcentration, the order of heavy metal accumulation in the plant was $\mathrm{As}>\mathrm{Cr}>\mathrm{Pb}>\mathrm{Hg}>\mathrm{Cd}$.

Alexander and Ubandoma (2014) investigated the levels of heavy metals in Amaranthus caudatus and Hibiscus sabdariffa in two farms, A and B. The order of the metal contamination in the vegetables were $\mathrm{Fe}>\mathrm{Cu}>\mathrm{Zn}$ in farm $\mathrm{A}$ and $\mathrm{Cu}>\mathrm{Fe}>\mathrm{Zn}$ in farm B. Aydinalp and Marinova (2003) studied that the presence of heavy metals in some agricultural soils. So, there is chance to enter these metals in the cultivated plants. Zheng et al., (2007) investigated that the inhabitants around Huludao zinc plant showed high health risk through the consumption of contaminated vegetables by the transfer of $\mathrm{Hg}, \mathrm{Pb}, \mathrm{Cd}, \mathrm{Zn}, \mathrm{Cu}$ from soil.

Based on persistent nature and cumulative behaviour as well as the probability of potential toxicity effects of vegetables and tubers, there is need to test and analyze these food items to ensure the levels of these trace elements meet the agreed international requirements. Knowledge of the contamination of tubers and vegetables with heavy metals from the areas of Kottayam has not yet been established. Desta et al., (2017) explained about the need of regular monitoring of irrigation water, otherwise it

Table 1: Heavy metal analysis in tubers and vegetables. will create the presence of heavy metals in water. The present study was undertaken with the aim to compare and investigate the concentration of some specific heavy metals $(\mathrm{Pb}, \mathrm{Cd})$ found in some selected tubers and vegetables from most polluted areas of Kottayam District.

\section{MATERIALS AND METHODS}

Study area: The study was conducted at designated sampling points representative of the markets from Kottayam, District of Kerala state. Kottayam lies between latitude $9^{\circ} 15^{\prime}$ and $10^{\circ} 21^{\prime}$ and longitude $76^{\circ} 22^{\prime}$ and $77^{\circ} 25^{\prime}$. The present study was carried out in three most polluted areas of Kottayam District. Three sampling sites chosen for the includes Changanacherry, Mukkoottuthara and Erattupetta (Table 1).

Collection of samples: The samples of various tubers and leafy vegetables were collected from from different market places of Kottayam District (Changanacherry -S1, Mukkoottuthara-S2 and Erattupetta-S3). The tubers include Elephant yam (Amorphophallus campanulatus Roxb.) belongs to the family Araceae. Colocasia (Colocasia esculenta L.Schott.,) is a genus of 25 or more species of flowering plant in the family Araceae.

Leafy vegetables include cabbage (Brassica oleracea L. var. capitata) is a member of the genus Brassica and the mustard family, Brassicaceae and Amaranthus called edible amaranth (Amaranthus tricolor L.,) belongs to

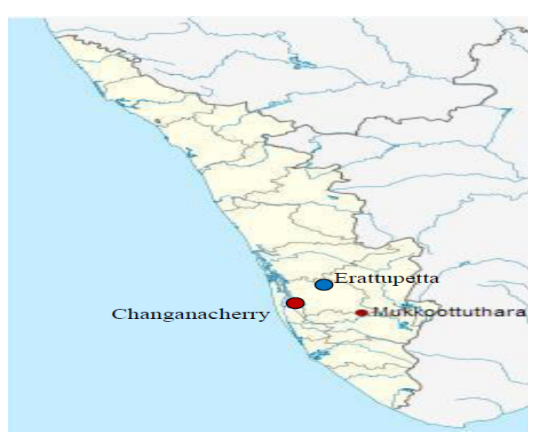

Fig 1: Site map of selected areas for the study.

\begin{tabular}{llcc}
\hline \multicolumn{2}{c}{ Tubers } & & \\
\hline Tubers & Markets & Conc. of Lead (mg/kg) & Conc. of Cd (mg/kg) \\
\hline Colocasia esculenta & Changanacherry (CC) & 0.124 & 0.545 \\
& Erattupetta (CE) & 0.087 & 0.012 \\
AmorphophallusCampanulatus & Mukkoottuthara (CM) & 0.150 & 0.010 \\
& Changanacherry (AC) & 0.182 & 0.254 \\
& Erattupetta (AE) & 0.173 & 0.018 \\
Leafy vegetables & Mukkoottuthara (AM) & 0.101 & 0.014 \\
Amaranthus tricolor & & & 0.746 \\
& Changanacherry (AC) & 0.115 & 0.023 \\
Brassica oleracea & Erattupetta (AE) & 0.222 & 0.028 \\
& Mukkoottuthara (AM) & 0.275 & 0.914 \\
& Changanacherry (BC) & 0.780 & 0.016 \\
\hline
\end{tabular}


Volume 53 Issue 4 (August 2019)

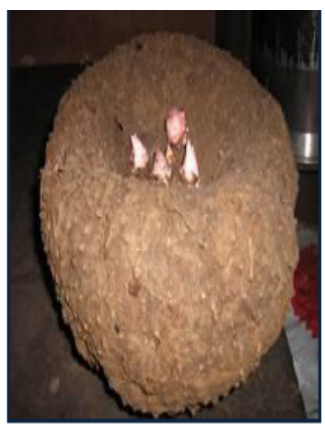

A

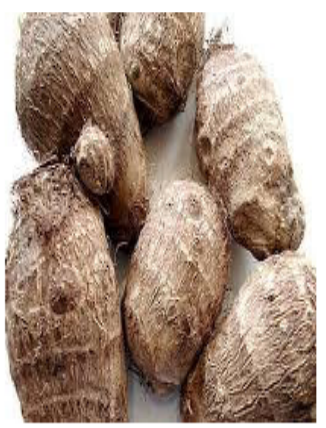

B

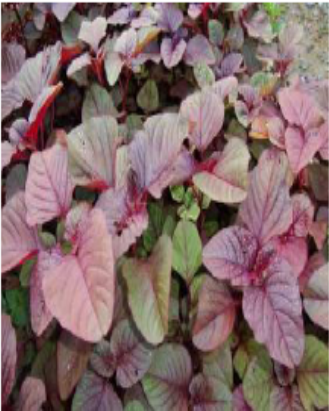

C

Fig 2: Tubers and Leafy Vegetables.

A) Amorphophallus campanulatus Roxb., B) Colocasia esculenta (L.) Schott., C) Amaranthus tricolor L., D) Brassica oleracea L. var. capitata.

Amaranthaceae family (Fig 2). All samples from different markets are collected and stored in clean polythene bags and brought to the laboratory for analyses.

Preparation and treatment of sample: The collected samples were washed with distilled water to remove the dust particles and were cut into small pieces using a clean knife, the pieces of vegetables were dried in an oven at $100^{\circ} \mathrm{C}$ for three days. After drying the samples were ground into a fine powder using a commercial blender and stored in polyethylene bags until used for acid digestion. The powdered samples were subjected to analysis for their heavy metal content.

Acid digestion and metal determination of samples: One gram of powdered plant samples were weighed and placed separately in a small beaker. Added $10 \mathrm{ml}$ concentrated $\mathrm{HNO}_{3}$ to each sample. Placed beaker in a stand and undisturbed overnight. Heated the beaker carefully on a hot plate until the production of red $\mathrm{NO}_{2}$ fumes has ceased and digestion become completed as was shown by a light coloured, clear solution. The samples were not permitted to dry during digestion. Cooled the beaker and added a small amount of $70 \%$ perchloric acid $\left(\mathrm{HClO}_{4}\right)$ usually $2-4 \mathrm{ml}$. Heated again and allowed to evaporate to a small volume.

The extract was filtered through whatman no: 42 filter paper. Transfered the sample to a $50 \mathrm{ml}$ standard flask and diluted to a volume with distilled water and used for analysis. Standards for the samples were also prepared in all cases for calibrations. Chemical analysis of heavy metal of both tubers and leafy vegetable samples carried out in the Atomic Absorption Spectrophotometric (AAS) method British (Pharmacopoeia, 2005).

The concentrations of heavy metals in every sample were determined three times, and the results were expressed as the mean concentration of heavy metal in the given sample (Singh et al., 2005).Concentration of the metal in both the tubers and leafy vegetables were computed as mg metal per $\mathrm{kg}$ dry samples $\left(\mathrm{mg} / \mathrm{kg}^{-1}\right)$.
Statistical analysis: All analysis was performed in triplicates. Results were expressed by mean of \pm SD. Statistical significance was established using one way analysis of variance (ANOVA), means were separated according to Duncan's multiple range analysis $(\mathrm{p}<0.05)$.

\section{RESULTS AND DISCUSSION}

Globally everyone is potentially vulnerable to the toxic effects of heavy metals. Many toxic heavy metals are ubiquitous in our environment. The accumulation of metals has been described as their content or concentration in different tubers and leafy vegetables on the basis of their amount per unit dry weight of tissues ( $\mathrm{mg} / \mathrm{kg}$ dry weight). The rate of accumulation of $\mathrm{Pb}$ and $\mathrm{Cd}$ are given in Table 2 and 3. The observed concentrations of $\mathrm{Pb}$ and $\mathrm{Cd}$ in the tubers and leafy vegetables were compared with the recommended limit as established by the WHO to assess the levels of food contamination.

The results obtained from the analysis revealed the levels of the heavy metals in vegetables and tubers were in excess levels when compared with the standard for maximum acceptable limits of WHO standards for heavy metals in food. The results indicated that higher levels of $\mathrm{Pb}$ were recorded in all of the samples analyzed when compared to the WHO permissible limits $(0.1 \mathrm{mg} / \mathrm{kg})$ for tubers and leafy vegetables, except in Colocasia esculenta collected from S3. In most of the samples, levels of Cd were found to be within safe limits of the WHO standard $(0.1 \mathrm{mg} / \mathrm{kg})$ but exceed high in both tubers and leafy vegetables from $\mathrm{S} 1$.

Lead is the main cause for concern in this work because it is highly toxic at minute concentration and can be harmful to man who may consume the affected tubers and leafy vegetables. Concentration of $\mathrm{Pb}$ in tubers ranged between from 0.087 from 0.182 . Pb being a serious cumulative body poison enters into the body system through air, water and food and cannot be removed by washing tubers and leafy vegetables. In case of tubers high accumulation of lead is found in Amorphophallus campanulatus from S1 (0.182) (Fig 1). In most of the tuber samples concentration 
of $\mathrm{Pb}$ was high, except in one case Colocasia esculenta collected from S3. In case of leafy vegetables the highest levels of $\mathrm{Pb}$ were observed in Brassica oleracea L.var.capitata from S1 (0.780) followed by Amaranthus tricolor L., which ranged between (0.115-0.275). (Fig 3). The results showed that the levels of $\mathrm{Pb}$ in all leafy vegetable samples were high ranges from (0.115-0.780).

Cadmium is a non-essential element in foods and natural waters and it accumulates primarily in the kidneys and liver (Divrikli et al., 2003). Regarding Cd accumulation, tubers and leafy vegetables collected from S3 and S2 showed normal levels of accumulation. But the Cd values were higher for both the tubers and leafy vegetable samples of S1. In tubers highest value was reported in Colocasia esculenta (0.545) as compared to Amorphophallus campanulatus (0.245). Not only tubers but leafy vegetables of S1 reported much higher levels of accumulation of $\mathrm{Cd}$. Highest value was analyzed in Brassica oleracea L.var.capitata (0.914) followed by Amaranthus tricolor L., (0.746) (Fig 4).

The obtained results showed that the amounts of $\mathrm{Pb}$ and $\mathrm{Cd}$ in the leafy vegetables were higher as compared to tubers. It was found that heavy metals accumulated more in leafy vegetables than those in other parts because these leaves considered as entry points of heavy metals from air (Muhammad et al., 2008). It is clearly evident from the present findings that leafy vegetables are accumulated of

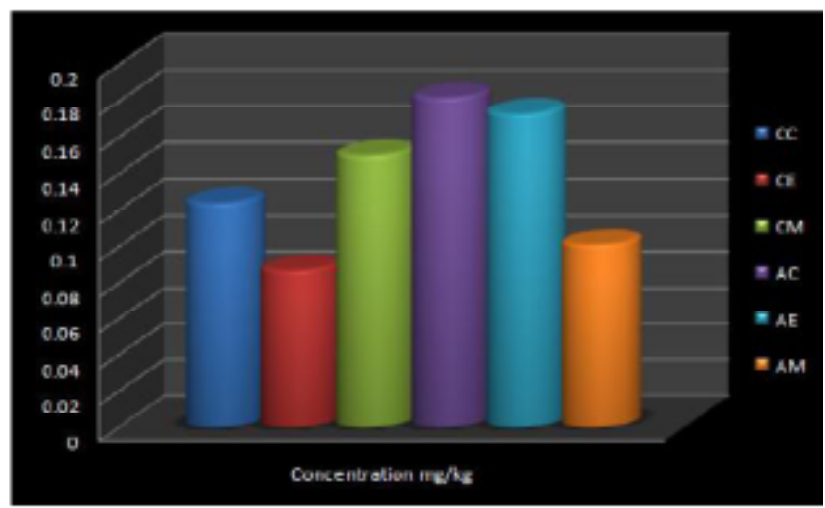

Fig 3: Rate of lead accumulation in tubers.

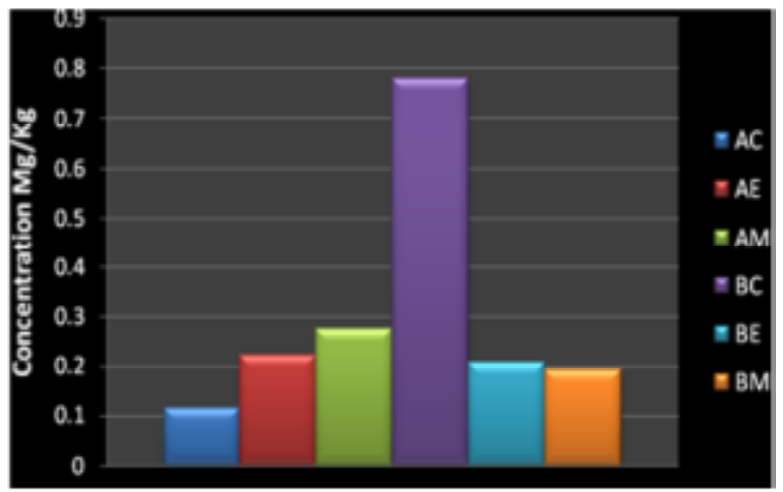

Fig 4: Rate of lead accumulation in leafy vegetables.

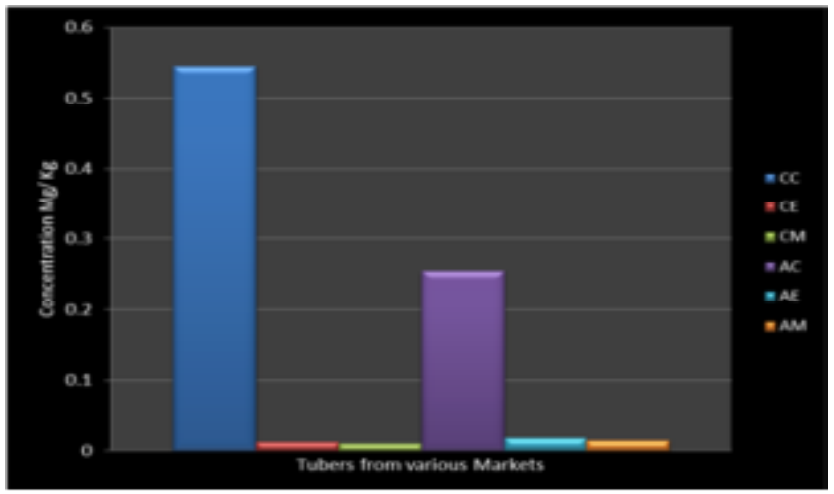

Fig 5: Rate of cadmium accumulation in tubers.

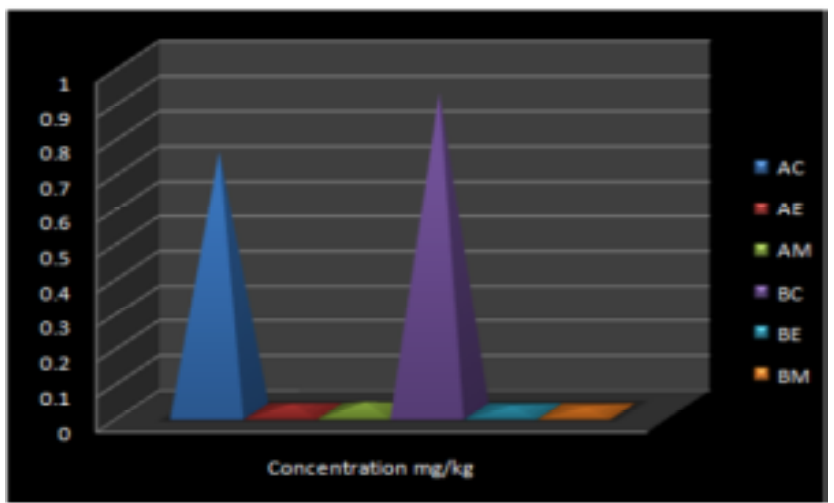

Fig 6: Rate of cadmium accumulation in leafy vegetables.

most of the non-essential heavy metals such as lead and cadmium. People especially those live within the Changanacherry area have a risk of $\mathrm{Pb}$ and $\mathrm{Cd}$ toxicity.

When compared to the samples of other two places, the samples of S1 showed the high contamination. The reasonable explanation is mainly attributed to these results are heavy traffic and they include the major industries and factories in Kottayam District leading to enforced heavy metals accumulation in the vegetables and tubers. There is no doubt, leafy vegetables and tubers obtained from neighbourhood of major highways can contain significant traces of $\mathrm{Pb}$ and $\mathrm{Cd}$ due to air borne metal particulates derived from vehicle emissions and other sources (Penny Farmer (2005).

Given the importance that the concentrations of $\mathrm{Pb}$ and $\mathrm{Cd}$ have for the quality of vegetables and tubers and their health safety, it is important to determine their concentrations. Cd content in S3 and S2 is safe in comparison to the suggested international food standard levels. However, for the $\mathrm{Pb}$ level, a special caution would need to be considered, since the $\mathrm{Pb}$ level in all samples in this study was higher than the international food standard levels. The consequence of trace metals in foods such as vegetables and tubers have been a considerable interest because of their toxicity effects which are important in the food diet of human beings (Asaolu et al., 1995). 


\section{CONCLUSION}

In conclusion, the results reported here confirm that the tubers and leafy vegetables collected from chosen market sites in the Kottayam area contained heavy metal contents more than the safe limits prescribed by the WHO especially $\mathrm{Pb} . \mathrm{Cd}$ values were within the safe limits except in $\mathrm{S} 1$. The samples collected from S1 had more concentration of heavy metals than those collected from other two markets. Secondly samples collected from S3 showed high heavy metal concentration than sample collected from S2. Thus it was determined that samples collected from S1 showed more contamination. Comparatively leafy vegetables contain more accumulation of heavy metal content as compared to tubers. The concentration of heavy metals especially $\mathrm{Pb}$ were significantly higher in tubers and vegetables than the WHO maximum acceptable limit for food and may cause serious health issues in human beings and also cause various diseases and disorders. Because of the high consumption of fruits and vegetables in the diet, it is very urgent to monitor the concentration of heavy metals.

It is therefore suggested that regular monitoring of heavy metals in tubers and leafy vegetables should be performed and alternative options should be carried out in order to prevent excessive accumulation of these heavy metals in the human food chain and ultimately cause risk to human health. Replication of such type of study should be performed where excessive vegetables are produced and consumed.

\section{ACKNOWLEDGEMENT}

This work was financially supported by Kerala State Council for Science, Technology \& Environment, (KSCSTE), Thiruvananthapuram.

\section{COMPETING INTERESTS}

The authors declare that they have no competing interests.

\section{REFERENCES}

Adepoju - Bello AA, Okeke CP, Bamgbade I, Oguntibeju OO (2013). Determination of the Concentration of Selected Heavy Metals in Indigenous Plant: Telfairia occidentalis. Alternative and Integrative Medicine. 2: 137- 1-4. doi:10.4172/2327-5162.1000137.

Agarwal SB, Anita Singh, Sharma RK, Agrawal M (2007). Bioaccumulation of heavy metals in vegetables; A threat to human health. Terrestrial and Aquatic Environmental Toxicology. 1(2):13-23.

Akan J. C., Kolo B. G., Yikala B. S., Ogugbuaja V. O. (2013). Determination of some heavy metals in vegetable samples from Biu Local Government Area, Borno State, North Eastern Nigeria. International Journal of Environmental Monitoring and Analysis. 1(2): 40-46. doi: 10.11648/j.ijema.20130102.11.

Alexander P, Ubandoma W H (2014). Determination of some heavy metals in selected edible vegetables grown along river Yedzaram in Uba area Adamawa State, Nigeria. African journal of PURE and Applied Chemistry. 8(4):78-82.http://www.academic journals. org/AJPAC.

Asaolu S S, Adefemi O S, Oyakilome I G, Ajibulu K E, Asaolu M F. (2012). Proximate and mineral composition of Nigerian leafy vegetables. Journal of Food Research. 1(3): 214-218. http://dx.doi.org/10.5539/jfr.v1n3p214.

Asaolu, S.S. (1995). Lead content of vegetables and tomatoes at Erekesan Market, Pak. J. Sci. Ind. Res. 38: 399.

Aydinalp C, Marinova S.2003. Distribution and forms of heavy metals in some agricultural soils. Polish Journal of Environmental Studies. 12 (5): 629-633.

Bhardwaj Richa, Gupta Anshu, Garg J.K. (2017). Evaluation of heavy metal contamination using environmetrics and indexing approach for River Yamuna, Delhi stretch, India. Water Science. 31: 52-66. http://dx.doi.org/10.1016/j.wsj.2017.02.002.

Bhuyan Simul, Abu Bakar Muhammad, Akhtar Aysha, Hossain M. Belal, Ali Mir Mohammad, (2017). Heavy metal contamination in surface water and sediment of the Meghna River, Bangladesh. Environmental Nanotechnology, Monitoring \& Management. 8: 273-279 .http://dx.doi.org/10.1016/j.enmm.10.003.

British Pharmacopoeia (2005) Atomic spectrophotometry: emmision and absorption, Appendix IID, CD.

Desta, Woldetsadik, Pay Drechsel, Bernard Keraita, Fisseha Itanna and Heluf Gebrekidan (2017). Heavy metal accumulation and health risk assessment in wastewater-irrigated urban vegetable farming sites of Addis Ababa, Ethiopia. International Journal of Food Contamination. 4(9): 1-13. https://doi.org/10.1186/s40550-017-0053-y.

Divrikli, U., Saracoglu, S., Soylak, M., Elci L. (2003). Determination of trace heavy metal contents of green vegetables samples from Kayseri-Turkey by flame atomic absorption spectrometry, Fresenius Environ.Bull. 12: 1123-1125.

Dore Venkatesh, Koti R.V. and Math K.K. (2018). Response of zinc application on growth, zinc content and grain yield of rice genotypes and correlation between zinc content and yield attributes of rice genotypes, Indian J. Agric. Res. 52(6): 625-630.

Lone Ashiq Hussain, Lal Eugenia P., Thakur Sasya, Ganie S. A., Wani Mohammad Saleem, (2013). Accumulation of heavy metals on soil and vegetable crops grown on sewage and tube well water irrigation. Scientific Research and Essays. 8(44): 2187-2193. DOI:10.5897/SRE2013.5636.

Muhammad Farooq, Farooq Anwar, Umer Rashid (2008). Appraisal of heavy metal contents in different vegetables grown in the vicinity of an industrial area, Pak. J. Bot.. 40(5): 2099-2106.

Murat Yabanl, Aykut Yozukmaz and Fatma Sel, (2014). Heavy Metal Accumulation in the Leaves, Stem and Root of the Invasive Submerged Macrophyte Myriophyllum spicatum L. (Haloragaceae): An Example of Kadın Creek (Mugla, Turkey). Brazilian Archives of Biology and Technology. 57(3): 434-440. http://dx.doi.org/10.1590/S1516-8913201401962.

Ndiokwere CC, Ezeh CA (1990). The occurrence of heavy metals in the vicinity of industrial complexes in Nigeria. Environ. Int. 16(29): 1- 295. 
Nriagu Jerome O., (1988). A global assessment of natural sources of atmospheric trace metals. Nature. 338: 47-49. https://doi.org/ $10.1038 / 333134 \mathrm{a} 0$.

Penny Farmer (2005). Lead pollution from Motor vehicles1974-86: A select Bibliography, Elsevier Science Publishing CO., INC. New York, NY 10017, USA pp.1-106.

Singh Vijayata, Yadav R.K, Yadav N.R, Yadav Rajesh, Malik R.S. and Singh Jogendra (2017). Identification of genomic Regions/ genes for high iron and zinc content and cross transferability of SSR markers in mungbean (Vigna radiata L.), Legume Research. 40(6): 1004-1011. DOI: 10.18805/lr.v40i04.9006.

Singh, V.K., Singh, K.P., Mohan, D., (2005). Status of heavy metals in water and bed sediments of River Gomti-a tributary of the Ganga River, India. Environ. Monit. Assess. 105: 43-67.

Smriti Rao P., Thomas Tarence, Hasan Amreen and David Ashish (2017). Determination of heavy metals contamination in soil and vegetable samples from Jagdalpur, Chhattisgarh State, India. International Journal of Current Microbiology and Applied Sciences. 6(8): 2909-2914. https://doi.org/10.20546/ijcmas.2017.608.348.

Sobukola, O.P, Adeniran, O.M., Odedairo, Kajihausa A.A, O.E. (2010). Heavy metal level of some fruits and leafy vegetables from selected, markets in Lagos, Nigeria. African Journal of Food Science. 4(2): 389-393.

Trajkovic Radmila, Kostic Milica, Jaksic Tatjana, Vasic Predrag, Andjelkovic Snezana, Babic Snezana and Stamenov Dragana (2018). The influence of lead acetate and actinomycetes on germination and growth of vetch plant (Vicia sativa L.). Legume Research, 41(5): 689-692.

Usman SOA, Ayodele JT (2002). Bioaccumulation of four heavy metals in leaves of Calotropis procera.J.Chem.Soc.Niger. 27: $26-27$.

Uwah EL, Dahi NP, Ogugbuaja VO (2009). Study of the level of some agricultural pollutants in soils and water leaf (Talinium triangulare) obtained in Maiduguri. Nigeria. Journal of Applied Sciences in Environmental Sanitation. 4(2):71-78.

Zheng N, Wang Q, Zheng. D. (2007). Health risk of $\mathrm{Hg}, \mathrm{Pb}, \mathrm{Cd}, \mathrm{Zn}$, and $\mathrm{Cu}$ to the inhabitants around Huludao Zinc Plant in China via consumption of vegetables. Sci Total Environ. 20: 383 (1-3):81-9. DOI: 10.1016/j.scitotenv.2007.05.002. 